\title{
Carotid and femoral intima-media thickness in relation to three candidate genes in a Caucasian population
}

\author{
Elisabeth J. Balkesteina, Ji Guang Wang ${ }^{b}$, Harry A.J. Struijker-Boudiera, \\ Cristina Barlassina ${ }^{\mathrm{c}}$, Giuseppe Bianchic, Willem H. Birkenhäger ${ }^{\mathrm{d}}$, Eva Brand ${ }^{\mathrm{e}}$, \\ Elly Den Hond ${ }^{\mathrm{b}}$, Robert Fagard ${ }^{\mathrm{b}}$, Stefan-Martin Herrmann ${ }^{\mathrm{e}}$, Luc M. Van Bortel ${ }^{f}$ \\ and Jan A. Staessen ${ }^{\mathrm{b}}$
}

\begin{abstract}
Background In a Caucasian population, the prevalence and incidence of hypertension, renal function and large artery stiffness were significantly correlated with polymorphisms in the genes encoding the angiotensinconverting enzyme (ACE I/D), aldosterone synthase $(-\mathrm{C} 344 \mathrm{~T})$ and the cytoskeleton protein $\alpha$-adducin (Gly460Trp).
\end{abstract}

Objective This study investigated intima-media thickening, a precursor of atherosclerosis, in relation to these genetic polymorphisms.

Methods Carotid and femoral intima-media thickness were assessed with a wall-track system in 380 subjects enrolled in a population study. Subjects were genotyped for the presence of the ACE D, aldosterone synthase $-344 \mathrm{~T}$ and $\alpha$-adducin 460Trp alleles. The statistical analysis allowed for confounders, interactions among genes, and the non-independence of the phenotypes within families.

Results The sample included 188 men (49.5\%). Mean age was $\mathbf{3 9 . 8}$ years. Intima-media thickness of the carotid and femoral arteries averaged 575 and $719 \mu \mathrm{m}$, respectively. Intima-media thickness of the femoral-but not carotidartery increased with the number of ACE D alleles. The effect of ACE genotype on femoral intima-media thickness was confined to carriers of the 460Trp allele and the $-344 \mathrm{~T}$ allele. Expressed as a percentage of the population mean, the mean differences between II and DD homozygotes averaged $13.4 \%(95 \% \mathrm{Cl} 5.6-21.2 \%)$ in all subjects, $21.2 \%(8.0-34.5 \%)$ in carriers of the 460Trp allele, $15.4 \%(4.1-26.8 \%)$ in carriers of the $-344 \mathrm{~T}$ allele, and $25.2 \%(10.7-39.7 \%)$ if the 460Trp and $-344 \mathrm{~T}$ alleles were both present.

Conclusion This study shows that a relationship exists

\section{Introduction}

We recently found in a Caucasian population that blood pressure, the prevalence and incidence of hypertension [1], renal function [2] and stiffness of the femoral and carotid arteries [3], were significantly correlated with polymorphisms in the genes encoding the angiotensinconverting enzyme (ACE I/D), aldosterone synthase between the intima-media thickness of the large muscular femoral artery and the ACE gene. This relationship is only apparent in the presence of either the $\alpha$-adducin 460Trp or the aldosterone synthase $-344 \mathrm{~T}$ allele. These findings may have clinical implications for the assessment of genetic cardiovascular risk. J Hypertens 20:1551-1561 (c) 2002 Lippincott Williams \& Wilkins.

Journal of Hypertension 2002, 20:1551-1561

Keywords: atherosclerosis, genetics, population, risk factor, intima-media thickness

${ }^{a}$ Cardiovascular Research Institute Maastricht, Capaciteitsgroep Farmakologie en Toxicologie, Universiteit Maastricht, Maastricht, The Netherlands,

${ }^{b}$ Hypertensie en Cardiovasculaire Revalidatie Eenheid, Departement voor Moleculair en Cardiovasculair Onderzoek, Katholieke Universiteit Leuven, Leuven, Belgium, ${ }^{\mathrm{C}}$ Divisione di Nefrologia Dialisi e Ipertensione, Ospedale San Raffaele, Dipartimento di Scienze e Techologie Biomediche, Universitá degli Studi di Milano, Milano, Italy, ${ }^{\mathrm{d} E r a s m u s ~ U n i v e r s i t e i t, ~ R o t t e r d a m, ~ T h e ~ N e t h e r l a n d s, ~}$ eUniversitätsklinikum Benjamin Franklin, Freie Universität Berlin, Berlin, Germany and ${ }^{f}$ Heymans Institute of Pharmacology, Ghent University, Ghent, Belgium.

Sponsorship: The FLEMENGHO Study was supported by research grants G.0174.97 and G.0291.98 from the Fonds voor Wetenschappelijk Onderzoek Vlaanderen (Brussels, Belgium), the Bilaterale Wetenschappelijke en Technische Samenwerking Vlaanderen-China (project BIL98/15) and a special research grant from the Katholieke Universiteit Leuven (Onderzoekstoelage OT99/28). Nuclear families were recruited in the framework of the European Project on Genes in Hypertension, which is supported by the European Union (contracts IC15-CT98-0329-EPOGH and QLG1-CT-2000-01137-EURNETGEN). Genetic studies in Berlin, Germany, were supported by grants from the Deutsche Forschungsgemeinschaft to E.B. (BR 1589/1-1) and to S.-M.H. (HE 2852/1-1) and by a grant from the Société Française d'Hypertension Artérielle to E.B.

Correspondence and requests for reprints to Jan A. Staessen, Study Coordinating Centre, Laboratory of Hypertension, University of Leuven, Campus Gasthuisberg, Herestraat 49, B-3000 Leuven, Belgium.

Tel: +32 1634 7104; fax: +321634 7106;

e-mail: jan.staessen@med.kuleuven.ac.be

Received 13 December 2001 Revised 22 March 2002 Accepted 23 April 2002

See editorial comment page 1477

$(\mathrm{C}-344 \mathrm{~T})$ and the cytoskeleton protein $\alpha$-adducin (Gly460Trp). Homozygous carriers of the ACE D allele showed a higher incidence of hypertension than the other ACE genotypes. The incidence of hypertension was further increased in ACE DD homozygotes who also carried the $\alpha$-adducin 460Trp allele [1]. In crosssectional analyses, systolic blood pressure and the 
prevalence of hypertension were significantly elevated among subjects who carried both the $\alpha$-adducin 460Trp and the aldosterone synthase $-344 \mathrm{~T}$ alleles [1]. Furthermore, serum creatinine and proteinuria were slightly, but significantly higher and creatinine clearance was lower in subjects having both the $\alpha$-adducin 460Trp and ACE D alleles [2]. Large artery stiffness was significantly related to the ACE I/D genotype, but this relationship depended on vascular territory and genetic background [3]. Carriers of the ACE D allele compared with II homozygotes, have systemically increased ACE levels, which may promote the local generation of angiotensin II [4,5] and hence vascular growth [6]. Intima-media thickening of the large arteries is a precursor of frank atherosclerosis and a harbinger of cardiovascular complications [7-9].

The hypothesis underlying previous studies was that interactions between the three candidate genes might raise blood pressure and influence renal function via stimulation of sodium reabsorption in the kidney and chronic expansion of the circulating fluid volume [1]. These mechanisms may be sufficient to engender structural changes in the wall of large arteries. To test this hypothesis, the effects of the three aforementioned candidate genes were investigated, alone and combined, on the intima-media thickness of the elastic common carotid artery and the muscular femoral artery in a subgroup of subjects enrolled in our population study [1].

\section{Methods}

\section{Study population}

The Flemish Study on Environment, Genes and Health Outcomes (FLEMENGHO) started in 1985. Its protocol was approved by the Ethics Committee of the University of Leuven, Belgium. From August 1985 until November 1990, a random sample of the households living in a geographically defined area of Northern Belgium was recruited [10]. To further investigate the role of genetic factors, from June 1996 until January 1999, the study population was enlarged with nuclear families, including children who were at least 10 years old, using the former participants as index persons. The participants or their parents gave informed consent. The participation rate among all subjects contacted was $64.3 \%[1-3]$.

For the present study, carotid and femoral intimamedia thickness were measured in 392 subjects. Because of missing values of potentially important confounding variables, 12 subjects were excluded, leaving 380 persons for analysis.

\section{Fieldwork}

Before the participants were examined at the field centre, they refrained from smoking, heavy exercise, and drinking alcohol or caffeine-containing beverages for at least $3 \mathrm{~h}$. Their blood pressure was measured five times consecutively after they had rested for $5 \mathrm{~min}$ and were sitting. Hypertension was diagnosed if the average of the five blood pressure readings was at least $140 \mathrm{mmHg}$ systolic or $90 \mathrm{mmHg}$ diastolic, or when the subjects were on antihypertensive medication. On a separate day, validated [11] oscillometric SpaceLabs 90202 or 90207 monitors (Redmond, Washington, USA) fitted with the same cuff size as for the conventional measurements, were programmed to obtain readings with an interval of $20 \mathrm{~min}$ for at least $12 \mathrm{~h}$ between 0800 and $2200 \mathrm{~h}$. Every month, the recorders were checked for accuracy against a mercury column. The mean daytime blood pressure was calculated from unedited recordings with weights according to the time interval between successive readings [12]. White-coat hypertension was assumed to be present if patients who were hypertensive on conventional measurement and who were untreated, had a daytime ambulatory blood pressure lower than 135 $\mathrm{mmHg}$ systolic and $85 \mathrm{mmHg}$ diastolic [12,13]. A venous blood sample was obtained for measurement of serum lipids, blood glucose and genotypes.

The same observer (E.J.B.) performed all vascular measurements, using a wall-tracking ultrasound system with a $7.5 \mathrm{MHz}$ probe [14]. She recorded the intimamedia thickness of the right common carotid artery $2 \mathrm{~cm}$ proximal of the bulb and that of the common femoral artery $1 \mathrm{~cm}$ proximal of the bifurcation into the profound and superficial branches. Simultaneously with the vascular measurements, blood pressure was recorded at $3 \mathrm{~min}$ intervals at the right upper arm with a semi-automated device (Dinamap 845, Applied Medical Reseach Corporation, Tampa, Florida, USA). The same operator measured off-line, the distances from the adventitia-media boundary of the near wall to the lumen-intima and media-adventitia interfaces of the far wall [15]. The intima-media thickness was computed as the mean difference between these distances measured over three separate intervals of $5.2 \mathrm{~s}$, which on average included 15 heart cycles. An atherosclerotic plaque was defined as a distinct area where the intima-media encroached into the vessel lumen and where its thickness was at least $50 \%$ greater than that of the adjacent sites [16]. When present, atheromatous plaques were included in the measurements of intima-media thickness. Repeatability was determined in 10 subjects, as previously described [15]. For the carotid intima-media thickness, the repeatability coefficients were $29 \mu \mathrm{m}$ below age 40 years and $40 \mu \mathrm{m}$ in older subjects. For the femoral artery, these coefficients were 41 and $46 \mu \mathrm{m}$, respectively. For all ages combined, the intra-observer intrasession coefficients of variability [17] amounted to ( \pm SD) $5.2 \pm 1.7 \%$ for the common carotid artery and to $5.6 \pm 4.6 \%$ for the femoral artery. 


\section{Determination of genotypes}

Genomic DNA was extracted from peripheral blood. The ACE I/D polymorphism was detected, as described by Lindpaintner et al. [18]. All samples initially genotyped as DD underwent a second polymerase chain reaction (PCR) with insertion-specific primers $[18,19]$. Allelic discrimination of the Gly460Trp $\alpha$-adducin polymorphism was carried out using a $5^{\prime}$ nuclease assay [20] on an ABI Prism 7700 apparatus (Perkin Elmer, Norwalk, Connecticut, USA). The forward and reverse primers and the 460Gly and 460Trp probes employed in the TAQMan assay were $5^{\prime}$ CGTCCACACCTTAGTCTTCGACTT-3'， 5'-GGAG AAGACAAGATGGCTGAACTC-3'， 5'-FAM-TTCCA TTCTGCCCTTCCTCGGA-TAMRA- $3^{\prime}$ and $5^{\prime}$-TET TTCCATTCTGCCATTCCTCGGAATAMRA-3', respectively. Per $25 \mu \mathrm{l}$, the PCR fluid contained $50 \mathrm{ng}$ DNA, $300 \mathrm{nmol}$ primers, $100 \mathrm{nmol}$ FAM-probe and $50 \mathrm{nmol}$ TET-probe. The amplification conditions were $50^{\circ} \mathrm{C}$ for $2 \mathrm{~min}, 95^{\circ} \mathrm{C}$ for $10 \mathrm{~min}, 95^{\circ} \mathrm{C}$ for $15 \mathrm{~s}$ and $62^{\circ} \mathrm{C}$ for $1 \mathrm{~min}$ for 40 cycles. For determination of the $\mathrm{C}-344 \mathrm{~T}$ aldosterone synthase gene variants, PCR and subsequent genotyping were performed as described by Brand et al. [21].

\section{Statistical methods}

For statistical analysis the SAS version 8.1 (SAS Institute, Cary, North Carolina, USA) and StatXact version 4.01 (Cytel Software Corporation, Cambridge, Massachusetts, USA) were used. Comparisons of means and proportions were performed with the standard normal z-test and Fisher's exact test, respectively. Significant co-variables of intima-media thickness were traced by stepwise linear regression. $P$-values for independent explanatory variables to enter and to stay in the model were set at $\sim 0.15$. The presence of atheromatous plaques in relation to genotype was studied by multiple logistic regression. In multiple linear and logistic regression, the genotypes were first represented by dummy variables using the deviation from mean coding approach [22], which does not imply any genetic hypothesis. In single-gene analyses in which independent hypotheses were tested, the $\alpha$-levels and confidence intervals were adjusted for multiple testing, using Bonferroni's method [23]. To formally test the prior hypothesis of genetic interactions between the three candidate genes [1-3], dummy variables were also used, coded according to the absence or presence of the risk conferring alleles ACE D, $\alpha$-adducin 460Trp, and aldosterone synthase -344T. Because family members are more likely to share identical alleles than randomly selected subjects and to allow for the non-independence of the arterial phenotypes within families, the analysis was repeated, using generalized estimating equations [24] as implemented in the PROC GENMOD procedure [25] of the SAS package. In these analyses, we treated families as clusters and we applied a user-defined working correlation matrix, based on the intrafamilial intraclass correlation coefficients observed in our study subjects.

\section{Results \\ Characteristics of the participants}

The 380 participants included 188 men $(49.5 \%)$ and 115 hypertensive patients (30.3\%), of whom 47 were on one or more blood pressure-lowering drugs. Antihypertensive treatment included diuretics in 19 patients, drugs inhibiting the renin system in 39 subjects $(n=28$ for $\beta$-blockers, $n=10$ for angiotensin converting-enzyme inhibitors, and $n=2$ for angiotensin type- 1 receptor blockers), and vasodilators in seven patients ( $n=5$ for calcium-channel blockers, and $n=2$ for $\alpha$ blockers). Overall, 18 subjects were taking lipid-lowering drugs. The daytime ambulatory blood pressure averaged $124.8 \pm 9.9 \mathrm{mmHg}$ systolic and $75.0 \pm 7.9$ $\mathrm{mmHg}$ diastolic in men. In women, these levels were $121.6 \pm 10.5 \mathrm{mmHg}$ and $73.6 \pm 7.6 \mathrm{mmHg}$, respectively. Of 68 untreated hypertensive patients, 47 $(69.1 \%)$ had white-coat hypertension.

The subjects ranged in age from 12 to 76 years (Table 1). Carotid and femoral intima-media thickness increased with age (Fig. $1, P<0.001$ ). Carotid or femoral atheromatous plaques were present in 16 men $(8.6 \%)$ and 12 women (6.2\%). Among men, 57 (30.3\%) were current smokers and $120(63.8 \%)$ reported intake of alcohol. In women, these numbers were $48(25.0 \%)$ and $72(37.5 \%)$, respectively. A total of 17 women $(8.9 \%)$ used oral contraceptives and none took hormonal replacement therapy.

\section{Genotype and allele frequencies}

The frequencies of the ACE $(P=0.37), \alpha$-adducin $(P=0.84)$ and aldosterone synthase $(P=0.16)$ genotypes did not deviate from Hardy-Weinberg equilibrium. Before (Table 2) and after adjustment for covariables, the relative risk of having atheromatous plaques was similar across all genotypes, regardless of whether single-gene effects or genetic interactions were tested.

\section{Intima-media thickness}

Stepwise regression analysis identified gender, age, body-mass index, mean arterial pressure, current smoking, serum low-density lipoprotein-cholesterol concentration, and use of antihypertensive medications as likely or significant determinants of the intima-media thickness of the carotid artery, femoral artery, or both (Table 3). Because the correlation coefficient between carotid and femoral intima-media thickness was 0.33 $(P<0.001)$, all analyses were adjusted for the aforementioned co-variables.

The $P$-value for the $t$-to-enter of lipid-lowering treatment 
Table 1 Characteristics of participants

\begin{tabular}{|c|c|c|c|}
\hline & Men $(n=188)$ & Women $(n=192)$ & $P$ \\
\hline \multicolumn{4}{|l|}{ Clinical characteristics } \\
\hline Age (years) & $39.7 \pm 15.3$ & $39.9 \pm 16.0$ & 0.89 \\
\hline Body-mass index $\left(\mathrm{kg} / \mathrm{m}^{2}\right)$ & $25.1 \pm 3.9$ & $24.7 \pm 4.7$ & 0.29 \\
\hline Systolic blood pressure $(\mathrm{mmHg})$ & $129 \pm 13$ & $124 \pm 14$ & $<0.001$ \\
\hline Diastolic blood pressure $(\mathrm{mmHg})$ & $80 \pm 10$ & $77 \pm 10$ & $<0.001$ \\
\hline Mean arterial pressure $(\mathrm{mmHg})^{*}$ & $92 \pm 10$ & $85 \pm 10$ & $<0.001$ \\
\hline Heart rate $(\mathrm{bpm})^{*}$ & $58 \pm 9$ & $64 \pm 9$ & $<0.001$ \\
\hline \multicolumn{4}{|l|}{ Arterial measurements } \\
\hline Carotid atheromatous plaques $(n)$ & $9(4.8)$ & $8(4.2)$ & 0.77 \\
\hline Femoral atheromatous plaques $(n)$ & $11(5.9)$ & $7(3.6)$ & 0.31 \\
\hline External diameter of carotid artery $(\mathrm{mm})^{\dagger}$ & $7.6 \pm 0.9$ & $7.0 \pm 0.8$ & $<0.001$ \\
\hline Carotid intima-media thickness $(\mu \mathrm{m})$ & $573 \pm 177$ & $577 \pm 216$ & 0.86 \\
\hline External diameter of femoral artery $(\mathrm{mm})^{\dagger}$ & $10.5 \pm 1.3$ & $9.0 \pm 1.1$ & $<0.001$ \\
\hline Femoral intima-media thickness $(\mu \mathrm{m})$ & $750 \pm 324$ & $688 \pm 224$ & 0.03 \\
\hline \multicolumn{4}{|l|}{ Biochemical measurements } \\
\hline Blood glucose $(\mathrm{mmol} / \mathrm{l})$ & $4.92 \pm 1.09$ & $5.15 \pm 1.44$ & 0.09 \\
\hline Total cholesterol $(\mathrm{mmol} / \mathrm{l})$ & $5.03 \pm 1.07$ & $5.10 \pm 1.03$ & 0.53 \\
\hline LDL-cholesterol (mmol//) & $2.84 \pm 0.96$ & $2.85 \pm 0.88$ & 0.96 \\
\hline HDL-cholesterol $(\mathrm{mmol} / \mathrm{l})$ & $1.23 \pm 0.28$ & $1.51 \pm 0.39$ & $<0.001$ \\
\hline Triglycerides (mmol/l) & $2.06 \pm 1.39$ & $1.59 \pm 0.86$ & $<0.001$ \\
\hline
\end{tabular}

Fig. 1

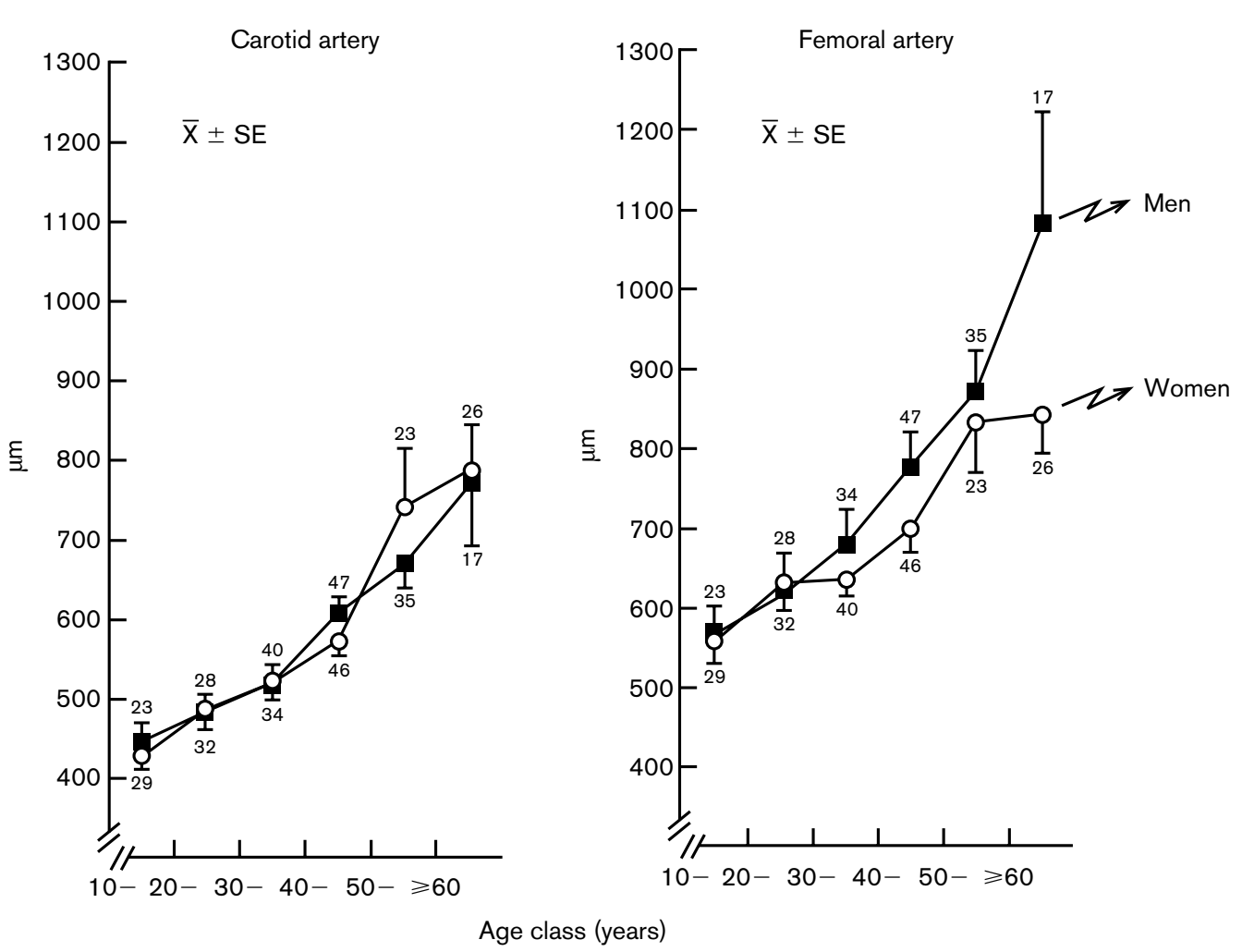

Intima-media thickness of the carotid and femoral arteries by sex and age class. Values are means \pm standard error. Solid squares and open circles denote men and women, respectively.

was 0.51 for the carotid artery and 0.005 for the femoral artery. However, the regression coefficients $( \pm S E)$ for current use of lipid-lowering drugs (coded 0 or 1 ) were positive $(27.0 \pm 40.4$ and $180.8 \pm 64.1)$ and therefore reflected bias-by-indication. Furthermore, the $P$-values for the $t$-to-enter were 0.29 or larger for the presence of white-coat hypertension and blood glucose concentration. Sensitivity analyses showed that accounting for 
Table 2 Genotype and allele frequencies

\begin{tabular}{lccccccc}
\hline Genes & \multicolumn{3}{c}{ Genotypes } & \multicolumn{3}{c}{ Alleles } \\
\hline ACE gene & $\mathrm{II}$ & $\mathrm{ID}$ & $\mathrm{DD}$ & $P^{\dagger}$ & $\mathrm{I}$ & $\mathrm{D}$ & $P^{\dagger}$ \\
No atheromatous plaques & $110(31.2)$ & $164(46.6)$ & $78(22.2)$ & & $384(54.5)$ & $320(45.5)$ & \\
Plaques present & $6(21.4)$ & $16(57.2)$ & $6(21.4)$ & 0.87 & $28(50.0)$ & $28(50.0)$ & 0.93 \\
$\alpha$-adducin gene & $\mathrm{GlyGly}$ & $\mathrm{GlyTrp}$ & $\operatorname{TrpTrp}$ & $P^{\dagger}$ & $\mathrm{Gly}$ & $\operatorname{Trp}$ & $P^{\dagger}$ \\
$\quad$ No atheromatous plaques & $202(57.4)$ & $128(36.3)$ & $22(6.3)$ & & $532(75.6)$ & $172(24.4)$ & \\
Plaques present & $11(39.3)$ & $14(50.0)$ & $3(10.7)$ & 0.30 & $36(64.3)$ & $20(35.7)$ & 0.22 \\
Aldosterone-synthase gene & $\mathrm{CC}$ & $\mathrm{CT}$ & $\mathrm{TT}$ & $P^{\dagger}$ & $\mathrm{C}$ & $\mathrm{T}$ & $P^{\dagger}$ \\
No atheromatous plaques & $73(20.7)$ & $188(53.4)$ & $91(25.9)$ & & $334(47.4)$ & $370(52.6)$ & \\
Plaques present & $4(14.3)$ & $15(53.6)$ & $9(32.1)$ & 0.95 & $23(41.1)$ & $33(58.9)$ & 0.79 \\
\hline
\end{tabular}

Values are given as numbers (\%). 'Fisher's exact test with Bonferroni's correction of the $P$-values was used to compare frequencies between subjects with and without atheromatous plaques.

Table 3 Results of stepwise regression analysis in 380 participants

\begin{tabular}{|c|c|c|c|c|}
\hline & Carotid IMT $(\mu \mathrm{m})$ & $P$ & Femoral IMT $(\mu \mathrm{m})$ & $P$ \\
\hline Coefficient of determination $\left(R^{2}\right)$ & 0.338 & & 0.191 & \\
\hline Intercept & 228 & & 616 & \\
\hline \multicolumn{5}{|l|}{ Partial regression coefficients $( \pm S E)$} \\
\hline Gender $(0,1)^{*}$ & NS & 0.38 & $-64.3 \pm 26.0$ & 0.014 \\
\hline Age (years) & $-3.92 \pm 2.78$ & & $1.57 \pm 4.17$ & \\
\hline Age $\left(\right.$ years $^{2}$ ) & $0.113 \pm 0.033$ & $<0.001^{\dagger}$ & $0.061 \pm 0.051$ & $<0.001^{\dagger}$ \\
\hline Body-mass index $\left(\mathrm{kg} / \mathrm{m}^{2}\right)$ & $4.44 \pm 2.32$ & 0.056 & NS & 0.32 \\
\hline Mean arterial pressure $(\mathrm{mmHg})$ & $1.32 \pm 0.95$ & 0.16 & NS & 0.97 \\
\hline White-coat hypertension $(0,1)^{\S}$ & NS & 0.29 & NS & 0.40 \\
\hline Intake of antihypertensive drugs $(0,1)^{\S}$ & NS & 0.51 & $81.4 \pm 43.6$ & 0.063 \\
\hline Blood glucose $(\mathrm{mmol} / \mathrm{l})$ & NS & 0.50 & NS & 0.62 \\
\hline Current smoking $(0,1)^{\S}$ & $49.3 \pm 18.8$ & 0.009 & $58.4 \pm 29.5$ & 0.049 \\
\hline LDL-cholesterol (mmol/l) & $19.3 \pm 11.3$ & 0.089 & NS & 0.81 \\
\hline
\end{tabular}

IMT, intima-media thickness; LDL, low-density lipoprotein; NS, non-significant $(P$-value for the $t$-to-enter into the model is presented). ${ }^{*}$ Men were coded as 0 and women as $1 .{ }^{\dagger} P$-value for the multiple partial correlation between IMT and both the linear and squared terms of age. "Measurement at the brachial artery obtained during the vascular examination by the Dinamap device. ${ }^{\S}$ Design variables were coded 0 or 1 if the condition was absent or present, respectively.

the latter three variables did not affect the conclusions. Therefore, in the present analysis, these three covariables were not allowed for.

Both before (Fig. 2) and after adjustment for the above co-variables, intima-media thickness of the femoral, but not carotid, artery was significantly associated with ACE genotype. For both arteries, none of the singlegene associations with the $\alpha$-adducin or aldosterone synthase genotypes reached statistical significance.

In a further step of the adjusted analysis, it was observed that the effect of the ACE genotype on femoral intima-media thickness was confined to carriers of the $\alpha$-adducin $460 \mathrm{Trp}$ allele or the aldosterone synthase $-344 \mathrm{~T}$ allele. In the presence of the 460Trp allele, the mean intima-media thickness was $59 \mu \mathrm{m}$ lower than the population mean in II homozygotes of the ACE gene, whereas in DD homozygotes it was on average $86 \mu \mathrm{m}$ higher than the population mean (Fig. $3)$. In carriers of the aldosterone synthase $-344 \mathrm{~T}$ allele, the corresponding deviations from the population mean amounted to -48 and $73 \mu \mathrm{m}$ (Fig. 4). In the presence of both the $\alpha$-adducin 460Trp and aldosterone synthase $-344 \mathrm{~T}$ alleles, these quantities were -52 and $123 \mu \mathrm{m}$, respectively (Fig. 5). Expressed as a percentage of the mean femoral intima-media thickness in the whole population, the differences between the II and DD homozygotes averaged $13.4 \%$ (95\% CI 5.6-21.2\%) in all subjects, $21.2 \%(8.0-34.5 \%)$ in carriers of the $\alpha$ adducin $460 \mathrm{Trp}$ allele, $15.4 \%(4.1-26.8 \%)$ in subjects having the aldosterone synthase $-344 \mathrm{~T}$ allele, and $25.2 \%(10.7-39.7 \%)$ if the latter alleles were both present.

Similar results were obtained if 28 subjects with plaques at any arterial site (carotid or femoral) were excluded. In this restricted sample, the differences between II and DD homozygotes averaged $11.7 \%$ (4.7-18.7\%). In 150 carriers of the $\alpha$-adducin $460 \mathrm{Trp}$ allele, in 279 carriers of the aldosterone synthase $-344 \mathrm{~T}$ allele, and in 123 carriers of both the 460Trp and $-344 \mathrm{~T}$ alleles, the differences between the II and DD homozygotes in the restricted group amounted to $18.3 \%(6.2-30.5 \%), 13.8 \%(3.6-24.0 \%)$ and $22.8 \%$ $(9.4-36.2 \%)$, respectively. 

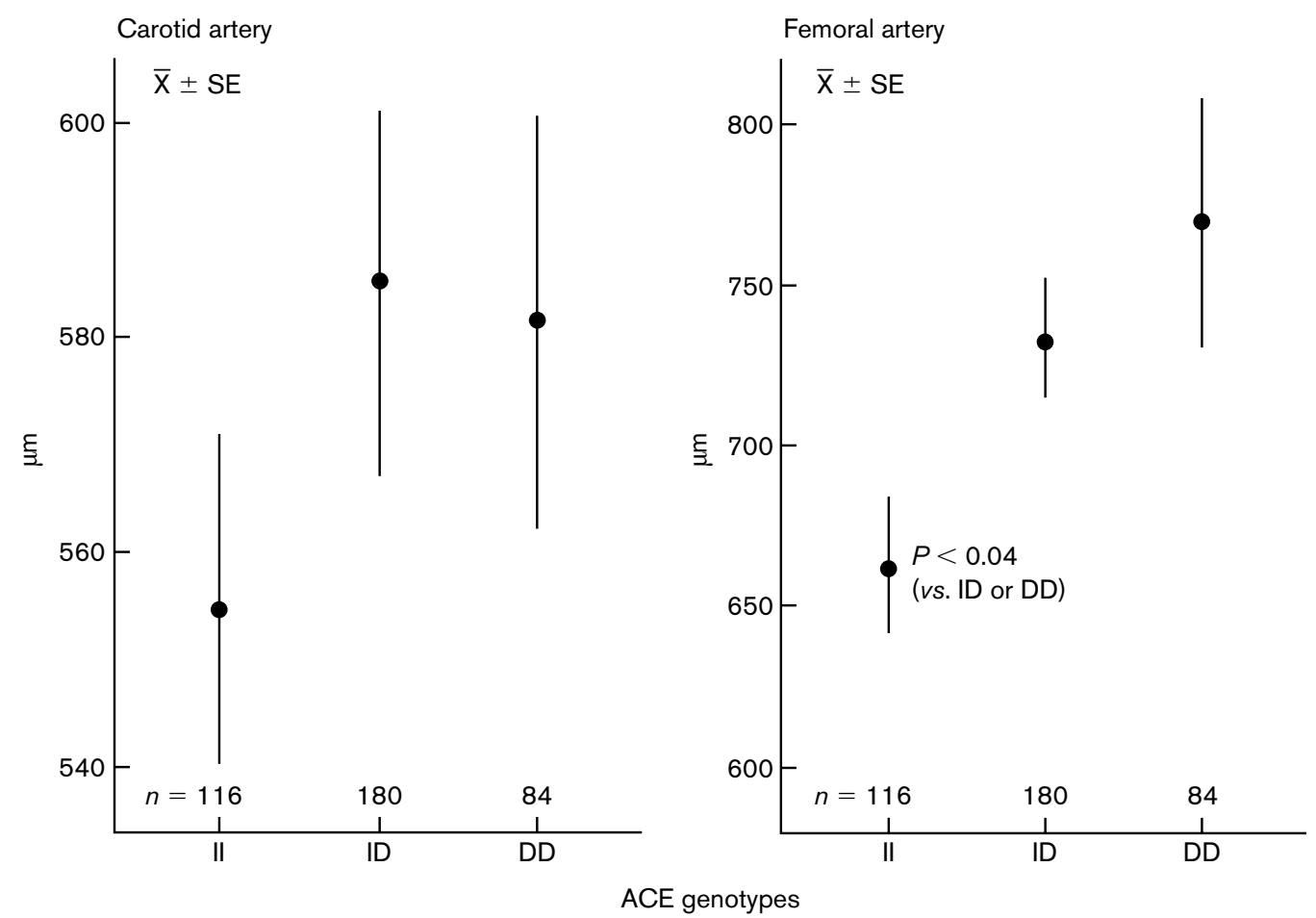

Intima-media thickness of the carotid and femoral arteries by angiotensin-converting enzyme (ACE) genotype. Values are unadjusted means \pm standard error. For each genotype the number of subjects is given.

Furthermore, the results were also confirmed after additional allowance for the non-independence of the intima-media thickness phenotype within families. The differences between the II and DD homozygotes averaged $12.5 \%(95 \%$ CI $3.7-21.3 \% ; P=0.005)$ in all subjects, $22.5 \%(7.0-38.1 \% ; P=0.005)$ in carriers of the $\alpha$-adducin 460 Trp allele, $12.9 \%(1.2-4.6 \% ; P=$ 0.03 ) in subjects having the aldosterone synthase $-344 \mathrm{~T}$ allele, and $27.5 \%(9.9-45.6 \% ; P=0.003)$ if the latter alleles were both present.

In further regression analyses in all subjects, the $\alpha$ adducin and aldosterone synthase genotypes were represented by dummy variables coded 0 or 1 depending on the absence or presence of the 460 Trp and -344T alleles and the ACE genotypes were coded as 0,1 or 2 according to the number of $\mathrm{D}$ alleles. The three-way interaction terms for the carotid and femoral arteries had $P$-values of 0.76 and 0.045 , respectively.

\section{Discussion}

In proximal elastic arteries hypertrophy of the wall is a marker of atherosclerosis, predominantly due to intima thickening, whereas in large or middle-sized muscular arteries this phenomenon mainly reflects remodelling of the media [26]. To the best of our knowledge, our study provides the first evidence of a synergism between the genes encoding ACE, $\alpha$-adducin and aldosterone synthase in relation to the intima-media thickness of the femoral artery. The mean differences between II and DD homozygotes of the ACE gene, expressed as a percentage of the population mean, amounted to $13.4 \%$ in all subjects. These differences averaged 21.2, 15.4 and $25.2 \%$, respectively, if the $\alpha$ adducin 460Trp allele, the aldosterone synthase $-344 \mathrm{~T}$ allele, or both alleles, were present. Less phenotypic precision when a dichotomous trait replaces a continuous one and the small number of cases $(n=28)$, probably explain the null findings with regard to the presence of atheromatous plaques. Because of the sample size required [1], blood pressure as an outcome variable in the present 380 subjects was not considered.

Few studies [27,28] reported on the genetic factors influencing femoral intima-media width and no investigator found a significant and positive association with the ACE D allele. Several studies [27-34] specifically addressed the possible relationship between the ACE I/ $\mathrm{D}$ polymorphism and carotid intima-media thickening. Most studies [29,31-33] reported negative results. In the Vobarno population study, the ACE D allele was found to be associated with carotid intima-media 

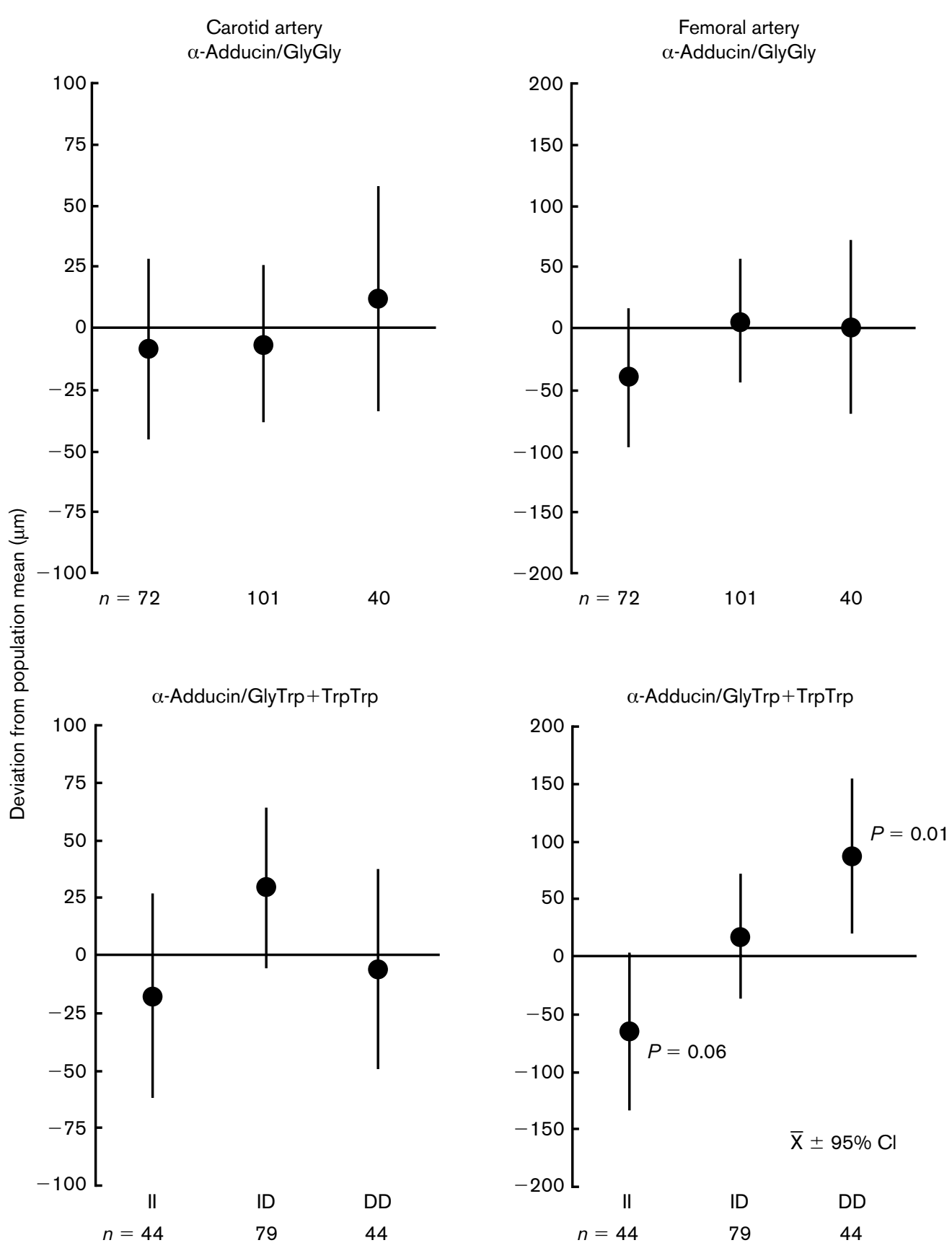

Intima-media thickness of the carotid and femoral arteries by angiotensin-converting enzyme (ACE) and $\alpha$-adducin genotypes. The measurements were adjusted for gender, age, age ${ }^{2}$, mean arterial pressure, body mass index, smoking, serum low-density lipoprotein-cholesterol concentration and intake of antihypertensive drugs. The results are expressed as deviations from the population mean with $95 \%$ confidence interval. For each combination of genotypes the number of subjects is given.

thickening, but not with the presence of carotid atherosclerotic plaques [30]. In a Finnish population study, non-smoking DD homozygotes had a significantly greater carotid intima-media thickness than did those with the II or ID genotypes [35]. In the total population, this association was weaker and it was reported to be absent in current smokers. In Japanese subjects [36], a positive correlation has been observed between the $\mathrm{D}$ allele and the presence of carotid plaques. In Chinese hypertensive subjects [34], a positive correlation was observed between the $\mathrm{D}$ allele and carotid intima-media thickening, but not with left ventricular 
Fig. 4
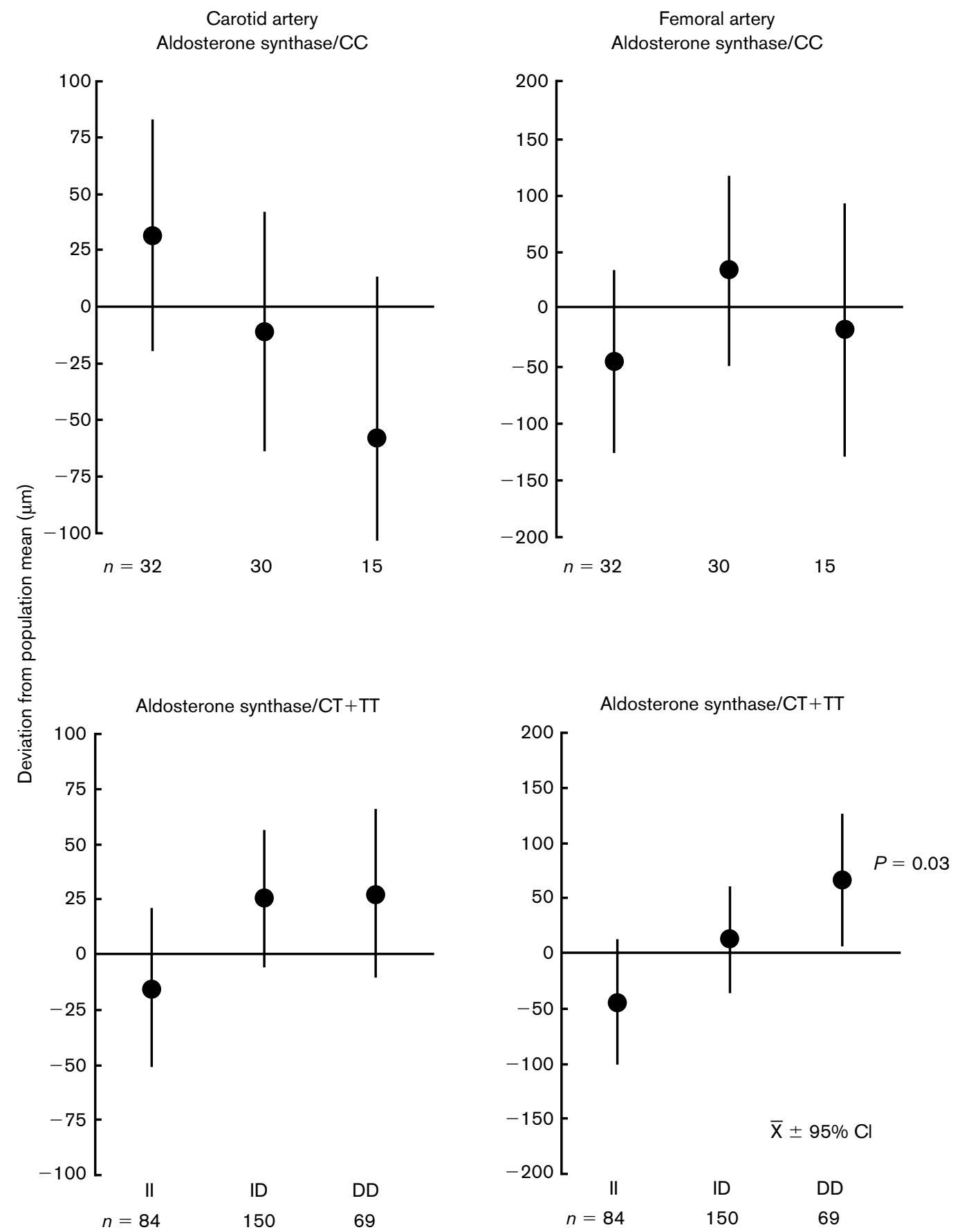

Intima-media thickness of the carotid and femoral arteries by angiotensin-converting enzyme (ACE) and aldosterone synthase genotypes. The measurements were adjusted for gender, age, age ${ }^{2}$, mean arterial pressure, body mass index, smoking, serum low-density lipoprotein-cholesterol concentration and intake of antihypertensive drugs. The results are expressed as deviations from the population mean with $95 \%$ confidence interval. For each combination of genotypes the number of subjects is given.

hypertrophy. Two quantitative reviews of the available literature $[37,38]$ also found significant associations between major atherosclerotic complications and the presence of the ACE D allele. However, no association between cardiovascular disease and the ACE I/D poly- morphism was reported in a meta-analyses of studies in Caucasians [39]. Some studies of the carotid artery included genetic variants other than the ACE I/D polymorphism, such as the M235T polymorphism of the angiotensinogen gene [33] or the A1166C poly- 

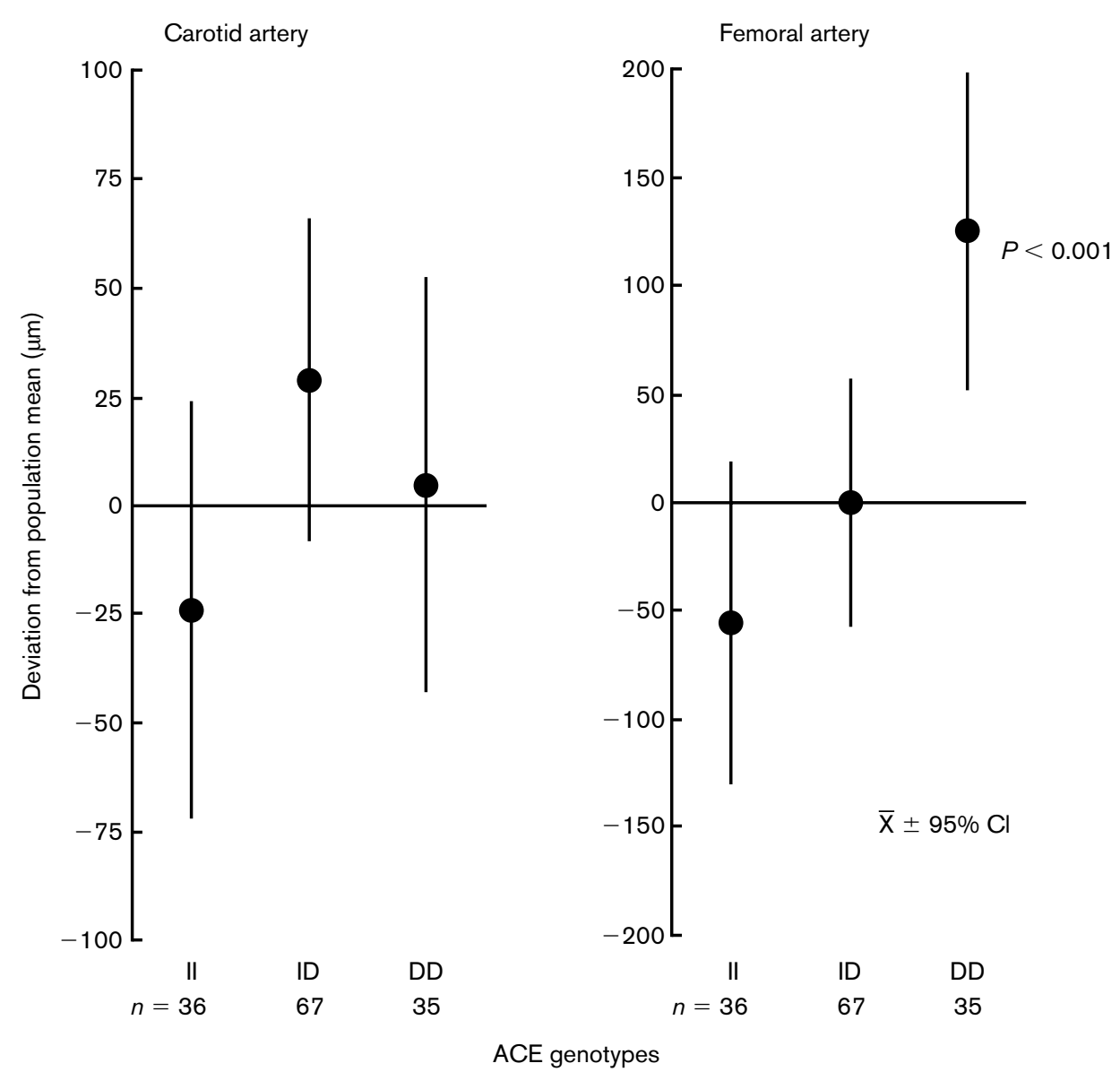

Intima-media thickness of the carotid and femoral arteries by angiotensin-converting enzyme (ACE) genotype in carriers of the $\alpha$-adducin $460 T r p$ and aldosterone-synthase $-344 \mathrm{~T}$ alleles. The measurements were adjusted for gender, age, age ${ }^{2}$, mean arterial pressure, body mass index, smoking, serum low-density lipoprotein-cholesterol concentration and intake of antihypertensive drugs. The results are expressed as deviations from the population mean with $95 \%$ confidence interval. For each combination of genotypes the number of subjects is given.

morphism of the angiotensin-II receptor gene [31]. However, no study formally tested for synergism between these candidate genes in relation to intimamedia thickness or the presence of atherosclerosis.

The present findings concerning the femoral intimamedia thickness are in line with the blood pressure results in a cross-sectional analysis of 1461 subjects drawn from the same population [1]. Systolic blood pressure and the prevalence of hypertension were significantly elevated among subjects who carried both the $\alpha$-adducin 460Trp allele and the aldosterone synthase $-344 \mathrm{~T}$ allele. In a recently published casecontrol study [40], a similar trend $(P=0.10)$ was observed in as few as 129 hypertensive patients and 129 normotensive controls. The presence of the ACE D allele is associated with higher systemic ACE levels [4], which probably stimulate the local generation of angiotensin II [5]. This may promote intima-media thickening. Hypertensive patients carrying the $\alpha$-adducin
460Trp allele, compared with those having the wildtype Gly460 variant, show an enhanced proximal tubular renal reabsorption of sodium [41] and experience larger blood pressure changes in response to sodium loading or diuretic treatment $[19,41,42]$. The presence of the $-344 \mathrm{~T}$ allele at the $\mathrm{C}-344 \mathrm{~T}$ locus in the promoter area of the aldosterone synthase gene stimulates aldosterone synthesis independently of the regulation by angiotensin II and potassium [43]. The mutated $\alpha$-adducin and high aldosterone secretion, both acting through sodium retention, may possibly lead to chronic expansion of the extracellular fluid volume and increased blood pressure and may, via these intermediary mechanisms, induce compensatory structural changes in the wall of large muscular arteries.

Williams et al. [44] examined the interactions between seven polymorphic genetic markers at four candidate loci in relation to hypertension. In single-gene analyses, there were no significant differences between 
normotensive and hypertensive subjects with respect to either allele or genotype frequencies. However, of 120 multilocus haplotypes, the distribution of 16 nonallelic combinations deviated significantly from random in the hypertensive patients, whereas among normotensive subjects no linkage disequilibrium was observed. This report [44], in line with the authors' present and previous findings [1-3], suggests that genetic interactions between multiple loci rather than single genes make up the genetic basis of cardiovascular disease and probably explain the inconsistencies between single-gene studies. Furthermore, crosssectionally and longitudinally measured phenotypes of the same trait, for instance blood pressure, may differ in their apparent genetic determination [1]. Environmental factors modulate the effects of the inherited genetic code. Genetic interactions may result in pleiotrophic effects according to the involved tissue type, as for instance in the present paper the intima-media of elastic as opposed to muscular arteries. These factors add further complexity to the genetic determination of multigenic cardiovascular disorders. Molecular biology may help bridging the gap between DNA sequencing and pathophysiological mechanisms and elucidate how cardiovascular disorders come about. For instance, further in-vitro studies should clarify whether the stimulation of the sodium pump in carriers of the $\alpha$ adducin 460 Trp allele is confined to renal tubular cells [41,42] or is ubiquitously present, in particular in vascular smooth muscle cells. The actively regulated intracellular $\mathrm{Na}^{+}$concentration may modulate the availability of free $\mathrm{Ca}^{2+}$ ions, which enhance contractility and stimulate cell growth $[45,46]$.

If confirmed, the present findings may have important clinical implications for the assessment of cardiovascular risk and the treatment of hypertension. Indeed, in the Angina Prognosis Study [9] carotid and femoral intima-media thickening and femoral plaques predicted the incidence of cardiovascular death and myocardial infarction and the need of revascularization procedures in unadjusted analyses involving 809 patients with coronary artery disease. After adjustment for sex, age, smoking, previous cardiovascular disease and lipid status, the risk of revascularization remained correlated with femoral intima-media thickness and the presence of atherosclerotic plaques in the femoral artery. After adjustment for the same co-variables, carotid intima-media thickness failed to predict any cardiovascular event, but the presence of carotid plaques predicted $(P=0.056)$ the risk of cardiovascular death or myocardial infarction.

\section{Conclusion}

Our findings suggest that intima-media thickness of large muscular arteries, such as the femoral artery, is influenced by synergism between the genes encoding ACE, $\alpha$-adducin and aldosterone synthase.

\section{Acknowledgements}

The Flemish population study would not have been possible without the collaboration of the family physicians of the participants. The municipality HechtelEksel (Belgium) provided logistic support. The authors acknowledge the expert assistance of Leszek Bieniaszewski, Rina Bollen, Hilde Celis, Lut De Pauw, Primoz Dolenc, Paul Drent, Dmitri Emelianov, Jerzy Gąsowski, Heng Fan, Lieve Gijsbers, Alida Hermans, Tatyana Kuznetsova, Tim Nawrot, Agnieszka Olszanecka, Katarzyna Stolarz, Lutgarde Thijs, Valérie Tikhonoff, Yvette Toremans, Sylvia Van Hulle, Celine Vanderkeilen, and Renilde Wolfs (Study Coordinating Centre, Leuven, Belgium). Brigitte Egbers (Berlin) determined the aldosterone-synthase genotypes.

\section{References}

1 Staessen JA, Wang JG, Brand E, Barlassina C, Birkenhäger WH, Herrmann SM, et al. Effects of three candidate genes on prevalence and incidence of hypertension in a Caucasian population. $J$ Hypertens 2001; 19:1349-1358.

2 Wang JG, Staessen JA, Tizzoni L, Brand E, Birkenhäger WH, Fagard R, et al. Renal function in relation to three candidate genes. Am J Kidney Dis 2001; 38:1158-1168.

3 Balkestein EJ, Staessen JA, Wang JG, van der Heijden-Spek JJ, Van Bortel L, Barlassina C, et al. Carotid and femoral artery stiffness in relation to three candidate genes in a white population. Hypertension 2001; 38:1190-1197.

4 Rigat B, Hubert C, Alhenc-Gelas F, Cambien F, Corvol P, Soubrier F. An insertion/deletion polymorphism in the angiotensin l-converting enzyme gene accounting for half the variance of serum enzyme levels. J Clin Invest 1990; 86:1343-1346.

5 Müller DN, Bohlender J, Hilgers KF, Dragun D, Costerousse O, Ménard J, et al. Vascular angiotensin-converting enzyme expression regulates local angiotensin II. Hypertension 1997; 29:98-104.

6 Morishita R, Gibbons GH, Ellison KH, Lee W, Zhang L, Yu H, et al. Evidence for direct local effect of angiotensin in vascular hypertrophy. In vivo gene transfer of angiotensin converting enzyme. J Clin Invest 1994; 94:978-984.

7 Grobbee DE, Bots ML. Carotid intima-media thickness as an indicator of generalized atherosclerosis. J Intern Med 1994; 236:567-573.

8 O'Leary DH, Polak JF, Kronmal RA, Manolio TA, Burke GL, Wolfson SK, Jr., et al. Carotid-artery intima and media thickness as a risk factor for myocardial infarction and stroke in older adults. N Engl J Med 1999; 340:14-22.

9 Held C, Hjemdahl P, Eriksson SV, Björkander I, Forslund L, Rehnqvist N. Prognostic implications of intima-media thickness and plaques in the carotid and femoral arteries in patients with stable angina pectoris. Eur Heart J 2001; 22:62-72.

10 Staessen JA, Roels HA, Emelianov D, Kuznetsova T, Thijs L, Vangronsveld J, et al. Environmental exposure to cadmium, forearm bone-density, and risk of fractures: prospective population study. Lancet 1999; 353:1140-1144.

11 O'Brien E, Waeber B, Parati G, Staessen J, Myers MG, on behalf of the European Society of Hypertension. Blood pressure measuring devices: recommendations of the European Society of Hypertension. Brit Med $J$ $2001 ; 322: 531-536$.

12 Staessen JA, Bieniaszewski L, O'Brien ET, Imai Y, Fagard R. An epidemiological approach to ambulatory blood pressure monitoring: the Belgian population study. Blood Press Monit 1996; 1:13-26.

13 The Joint National Committee on Prevention Detection Evaluation and Treatment of High Blood Pressure. The Sixth Report of the Joint National Committee on Prevention, Detection, Evaluation, and Treatment of High Blood Pressure. Arch Intern Med 1997; 157:2413-2446.

14 Hoeks APG, Brands PJ, Smeets FAM, Reneman RS. Assessment of the distensibility of superficial arteries. Ultrasound Med Biol 1990; 16: $121-128$.

15 Willekes C, Hoeks APG, Brands PJ, Williger JM, Reneman RS. Evaluation 
of off-line automated intima-media thickness detection of the common carotid artery based on M-line signal processing. J Vasc Res 1999; 36:222-228.

16 Salonen JT, Salonen R. Ultrasound B-mode imaging in observational studies of atherosclerotic progression. Circulation 1993; 87 (suppl II): II-57-II-65.

17 Kool MJF, van Merode T, Reneman RS, Hoeks APG, Struijker Boudier HAJ, Van Bortel L. Evaluation of reproducibility of a vessel wall movement detector system for assessment of large artery properties. Cardiovasc Res 1994; 28:610-614.

18 Lindpaintner K, Pfeffer MA, Kreutz R, Stampfer MJ, Grodstein F, LaMotte $F$, et al. A prospective evaluation of an angiotensin-converting-enzyme gene polymorphism and the risk of ischemic heart disease. N Engl J Med 1995; 332:706-711.

19 Barlassina C, Norton GR, Samani NJ, Woodwiss AJ, Candy GC, Radevski I, et al. $\alpha$-Adducin polymorphism in hypertensives of South African ancestry. Am J Hypertens 2000; 13:719-723.

20 Livak KJ, Flood SJ, Marmaro J, Giusti W, Deetz K. Oligonucleotides with fluorescent dyes at opposite ends provide a quenched probe system useful for detecting PCR product and nucleic acid hybridization. PCR Methods Appl 1995; 4:357-362.

21 Brand E, Chatelain N, Mulatero P, Féry I, Curnow K, Jeunemaitre X, et al. Structural analysis and evaluation of the aldosterone synthase gene in hypertension. Hypertension 1998; 32:198-204.

22 Hosmer DW, Jr., Lemeshow S. Interpretation of coefficients. In: Applied logistic regression. New York, New York, USA: John Wiley \& Sons; 1989, pp. 38-81.

23 Bland JM, Altman DG. Multiple significance tests: the Bonferroni method. Brit Med J 1995; 310:170.

24 Trégouët DA, Ducimetière $P$, Tiret $L$. Testing associations between candidate-gene markers and phenotype in related individuals by use of estimating equations. Am J Hum Genet 1997; 61:189-199.

25 The SAS Institute. The GENMOD procedure. In SAS Online Doc Version 7.1: SAS/STAT, SAS Online Doc Version 7.1. Cary, NC, USA; 2000:1311-1411.

26 Girerd X, Mourad JJ, Copie X, Moulin C, Acar C, Safar M, et al. Noninvasive detection of an increased vascular mass in untreated hypertensive patients. Am J Hypertens 1994; 7:1076-1084.

27 Hosoi M, Nishizawa Y, Kogawa K, Kawagishi T, Konishi T, Maekawa K, et al. Angiotensin-converting enzyme gene is associated with carotid arterial wall thickness in non-insulin-dependent diabetic patients. Circulation 1996; 94:704-707.

28 Kogawa K, Nishizawa Y, Hosoi M, Kawagishi T, Maekawa K, Shoji T, et al. Effect of polymorphism of apolipoprotein $E$ and angiotensinconverting enzyme genes on arterial wall thickness. Diabetes 1997; 46:682-687.

29 Dessii-Fulgheri P, Catalini R, Sarzani R, Sturbini S, Siragusa N, Guazzarotti $\mathrm{F}$, et al. Angiotensin converting enzyme gene polymorphism and carotid atherosclerosis in a low-risk population. J Hypertens 1995; 13:1593-1596.

30 Castellano M, Mulesan ML, Rizzoni D, Beschi M, Pasini G, Cinelli A, et al. Angiotensin-converting enzyme I/D polymorphism and arterial wall thickness in general population. The Vobarno study. Circulation 1995; 91:2721-2724.

31 Girerd X, Hanon O, Mourad JJ, Boutouyrie P, Laurent S, Jeunemaitre X. Lack of association between renin-angiotensin system, gene polymorphisms, and wall thickness of the radial and carotid arteries. Hypertension 1998; 32:579-583.

32 Huang XH, Loimaala S, Nenonen A, Mercuri M, Vuori I, Pasanen M, et al. Relationship of angiotensin-converting enzyme gene polymorphism to carotid artery wall thickness in middle-aged men. $J$ Mol Med 1999; 77:853-858.

33 Arnett DK, Borecki IB, Ludwig EH, Pankow JS, Myers R, Evans G, et al. Angiotensinogen and angiotensin converting enzyme genotypes and carotid atherosclerosis: the atherosclerotic risk in communities and the NHLBI family heart studies. Atherosclerosis 1998; 138:111-116.

34 Jeng JR. Carotid thickening, cardiac hypertrophy, and angiotensin converting enzyme gene polymorphism in patients with hypertension. $A m \mathrm{~J}$ Hypertens 2000; 13:111-119.

35 Kauma H, Päivänsalo M, Savolainen MJ, Rantala AO, Kiema TR, Lilja M, et al. Association between angiotensin converting enzyme gene and polymorphism and carotid atherosclerosis. J Hypertens 1996; 14: 1183-1187.

36 Watanabe $\mathrm{Y}$, Ishigami T, Kawano Y, Umahara T, Nakamori A, Mizushima $\mathrm{S}$, et al. Angiotensin-converting enzyme gene I/D polymorphism and carotid plaques in Japanese. Hypertension 1997; 30 (part 2): 569-573.

37 Samani NJ, Thompson JR, O'Toole L, Channer K, Woods KL. A metaanalysis of the association of the deletion allele of the angiotensin- converting enzyme with myocardial infarction. Circulation 1996; 94: 708-712.

38 Wang JG, Staessen JA. Genetic polymorphisms in the renin-angiotensin system: relevance for susceptibility to cardiovascular disease. Eur J Pharmacol 2001; 410:289-302.

39 Agerholm-Larsen B, Nordestgaard BG, Tybjærg-Hansen A. ACE gene polymorphism in cardiovascular disease. Meta-analysis of small and large studies in whites. Arterioscler Thromb Vasc Biol 2000; 20:484-492.

40 Clark CJ, Davies E, Anderson NH, Farmer R, Friel E, Fraser R, et al. $\alpha$-Adducin and angiotensin I-converting enzyme polymorphisms in essential hypertension. Hypertension 2000; 36:990-994.

41 Bianchi G, Cusi D. Association and linkage analysis of $\alpha$-adducin polymorphism: is the glass half full or half empty? Am J Hypertens 2000; 13:739-743.

42 Barlassina C, Schork NJ, Manuta P, Citterio L, Sciarrone MT, Lanella G, et al. Synergistic effect of $\alpha$-adducin and ACE genes causes blood pressure changes with body sodium and volume expansion. Kidney Int 2000; 57:1083-1090.

43 Clyne CD, Zhang Y, Slutsker L, Mathis JM, White PC, Rainey WE. Angiotensin II and potassium regulate human CYP11B2 transcription through common cis elements. Mol Endocrinol 1997; 11:638-649.

44 Williams SM, Addy JH, Phillips JAI, Dai M, Kpodonu J, Afful J, et al. Combinations of variations in multiple genes are associated with hypertension. Hypertension 2000; 36:2-6.

45 Blaustein MP, Hamlyn JM. Pathogenesis of essential hypertension. A link between dietary salt and high blood pressure. Hypertension 1991; 18: III-184-III-195.

46 Blaustein MP, Hamlyn JM. Sodium transport inhibition, cell calcium, and hypertension. The natriuretic hormone/ $\mathrm{Na}^{+}-\mathrm{Ca}^{2+}$ exchange/hypertension hypothesis. Am J Med 1984; 77:45-59. 